\title{
Surveillance report of Zika virus among Canadian travellers returning from the Americas
}

\author{
Andrea K. Boggild MD, Jennifer Geduld MHSc, Michael Libman MDCM, Cedric P. Yansouni MD, \\ Anne E. McCarthy MD, Jan Hajek MD, Wayne Ghesquiere MD, Yazdan Mirzanejad MD, Jean Vincelette MD, \\ Susan Kuhn MD, Pierre J. Plourde MD, Sumontra Chakrabarti MD, David O. Freedman MD, Kevin C. Kain MD
}

Cite as: CMAJ 2017 March 6;189:E334-40. doi: 10.1503/cmaj.161241

CMAJ Podcasts: author interview at https://soundcloud.com/cmajpodcasts/161241-res

Visual abstract available at www.cmaj.ca/lookup/suppl/doi:10.1503/cmaj.161241/-/DC1

\begin{abstract}
BACKGROUND: Widespread transmission of Zika virus in the Americas has occurred since late 2015. We examined demographic and travel-related characteristics of returned Canadian travellers with Zika infection acquired in the Americas to illuminate risk factors for acquisition and the clinical spectrum.
\end{abstract}

METHODS: We analyzed demographic and travel-related data for returned Canadian travellers who presented to a CanTravNet site between October 2015 and September 2016 for care of Zika virus acquired in the Americas. Data were collected with use of the GeoSentinel Surveillance Network data platform.
RESULTS: During the study period, 1118 travellers presented to a CanTravNet site after returning from the Americas, 41 (3.7\%) of whom had Zika infection. Zika infection from the Americas was diagnosed at CanTravNet sites as often as dengue $(n=41)$ over the study period. In the first half of the study period, Zika virus burden was borne by people visiting friends and relatives in South America. In the latter half, coincident with the increased spread of Zika throughout the Caribbean and Central America, Zika virus occurred more often in tourists in the Caribbean. Forty (98\%) of the travellers with Zika infection acquired it through probable mosquito exposure, and 1 had confirmed sexual acquisition. Congenital transmission occurred in 2 of 3 pregnancies. Two (5\%) of those with Zika had symptoms resembling those of Guillain-Barré syndrome, 1 of whom also had Zika viral meningitis.

INTERPRETATION: Even in this small cohort, we observed the full clinical spectrum of acute Zika virus, including adverse fetal and neurologic outcomes. Our observations suggest that complications from Zika infection are underestimated by data arising exclusively from populations where Zika is endemic. Travellers should adhere to mosquito-avoidance measures and barrier protection during sexual activity.
A Ithough Zika virus was introduced to the Americas in $2013,{ }^{1}$ widespread transmission became recognized in late $2015,{ }^{2-4}$ with the Pernambuco state of Brazil serving as the epicentre of what has evolved into an international crisis., Within weeks, transmission became increasingly dispersed across the Americas such that, at the time of writing, autochthonous Zika transmission was documented in 50 countries of the Americas, including the United States. ${ }^{7}$ Cases acquired in the Americas are being exported around the globe with regularity, ${ }^{8,9}$ and secondary sexual transmission of Zika virus in nonendemic areas is now well described. ${ }^{10,11}$ In addition, new clinical syndromes attributable to Zika virus are becoming increasingly recognized, ${ }^{12}$ although how frequently these syndromes occur among exported versus endemic cases is unknown.

Many series to date have documented the epidemiologic features and clinical spectrum of Zika virus exported to other coun- tries. ${ }^{8,9,13}$ Data specific to Canadian travellers with Zika infection have yet to be synthesized, which constitutes an important knowledge gap owing to the lack of vectorial transmission of Zika in Canada. Given that Canadians are a highly mobile population, we present a Canada-specific surveillance summary of Zika infection in a cohort of Canadian travellers returning from the Americas who presented for care to a CanTravNet site over a 1-year period.

\section{Methods}

\section{Data source}

Seven Canadian sites in large urban centres from 5 provinces (British Columbia, Alberta, Manitoba, Ontario and Quebec) constitute CanTravNet, as previously described. ${ }^{14}$ CanTravNet represents the only sentinel surveillance network for travel-acquired 
illness in Canada. It provides situational awareness support to the Public Health Agency of Canada. Recent surveillance analyses using CanTravNet data in collaboration with the Public Health Agency of Canada have shown consistent capture of about $15 \%$ of travel-acquired illnesses imported to Canada.

CanTravNet sites are all members of GeoSentinel, a global surveillance network of the International Society of Travel Medicine. The GeoSentinel network is situated on 6 continents and has strict affiliation criteria, including recognized travel medicine expertise on the part of site directors and high volumes of ill returned travellers cared for at individual sites. Demographic and travel-related data are collected using the GeoSentinel data platform, as previously described ${ }^{15}$ (for additional details see www.istm.org/geosentinel). The GeoSentinel data collection protocol is reviewed cyclically by the institutional review board officer at the National Center for Emerging and Zoonotic Infectious Diseases at the US Centers for Disease Control and Prevention. The protocol is classified as public health surveillance, not human-subjects research requiring submission to and approval from institutional review boards. Final diagnoses include specific causes (e.g., Zika virus) and syndromes (e.g., rash).

\section{Definitions and classifications}

We used 5 travel-purpose designations, coded into the GeoSentinel data collection document: tourism; business; missionary/volunteer/ research/aid work; visiting friends and relatives; and education. The designation "visiting friends and relatives" has been previously described. ${ }^{16}$ Month of acquisition was defined by date of symptom onset in relation to the median probable incubation period: symptom onset within the first 4 days of a given month was ascribed as acquisition in the prior month, and symptom onset between the fifth to the last day of a given month was attributed to acquisition in that month. Objective neurologic impairment (e.g., meningitis, encephalitis, myelitis, Guillain-Barré syndrome or neuropathy) and congenital infection were considered to be severe complications of Zika infection. Dengue was considered to be severe if accompanied by plasma leakage, third-spacing of fluid, hemorrhagic complications, end-organ damage, or respiratory distress as defined by the World Health Organization. ${ }^{17}$

\section{Inclusion criteria}

We extracted and analyzed demographic, clinical and travel-related data on ill Canadians returning from travel to the Americas, and non-Canadians who fell ill during their travel to Canada, who were encountered at any of 7 CanTravNet sites from Oct. 1, 2015, to Sept. 30, 2016. We included only patients who had a final diagnosis of Zika virus infection confirmed either serologically (i.e., positive result on IgM enzyme-linked immunosorbent assay and plaque reduction neutralization test performed at Canada's National Microbiology Laboratory) or by real-time polymerase chain reaction (PCR). Diagnostic testing algorithms in Canada support the use of both PCR and serologic testing during the acute stage of illness (i.e., within the first $14 \mathrm{~d}$ ), and only serologic testing beyond the acute stage.

\section{Statistical analysis}

Extracted data were managed in a Microsoft Access database. Travellers were described by purpose of travel, demographic characteristics, presence or absence of a pre-travel medical encounter, destination and method of diagnosis. Women of child-bearing age were defined as those between 15 and 49 years of age. Differences between groups of travellers were compared with the use of the Fisher exact test or, in the case of continuous variables, the Mann-Whitney rank sum test. All statistical computations were performed with the use of GraphPad Prism software (GraphPad Software Inc.).

\section{Results}

During the study period, 1118 ill travellers presented to a CanTravNet site after returning from the Americas. Of these, 41 (3.7\%) were found to have Zika virus infection, 41 (3.7\%) dengue and $23(2.1 \%)$ chikungunya. As of Oct. 6, 2016, the Government of Canada had reported 330 confirmed cases of Zika virus infection (14 of which occurred in pregnant women) in Canada;18 thus, the CanTravNet cases accounted for $12 \%$ of the national burden. Twenty-four (59\%) of the travellers with Zika in our study were women, of whom 19 (79\%) were of child-bearing age, and $3(12 \%)$ were pregnant. Forty $(98 \%)$ of the travellers with Zika virus infection acquired it through probable mosquito exposure, and 1 (2\%) had confirmed sexual acquisition. The median age was 36 years (range 13-70 yr; interquartile range [IQR] 30-53 yr).

Most of the Zika cases occurred in Canadians who were travelling as tourists ( $n=17 ; 41 \%)$ or were visiting friends and relatives ( $n=15 ; 37 \%$ ); the remainder were travelling for business ( $n=4 ; 10 \%)$, missionary/aid work $(n=4 ; 10 \%)$ or educationrelated travel $(n=1 ; 2 \%)$ (Table 1$)$. Within the Americas, the most common region of exposure was the Caribbean $(n=22$; $54 \%$ ), followed by Central America ( $n=10 ; 24 \%)$ and South America ( $n=8 ; 20 \%$ ) (Table 1$)$. The 1 case of sexual acquisition occurred in Canada from a partner who had been infected in the Caribbean. The top countries of exposure were Colombia $(n=7$; $17 \%)$, Trinidad and Tobago ( $n=6 ; 15 \%)$, Nicaragua $(n=5 ; 12 \%)$, Barbados $(n=3 ; 7 \%)$, El Salvador $(n=3 ; 7 \%)$ and Martinique $(n=$ $3 ; 7 \%)$; only $1(2 \%)$ of the cases was acquired in Brazil, and none in Florida. The most common months of acquisition were August $(n=9 ; 22 \%)$, July $(n=8 ; 20 \%)$ and December $(n=6 ; 15 \%)$ (Figure 1). The median duration of travel was 15 days (range 4-420 d; IQR 10-28 d).

Over the course of the outbreak in the Americas, the epidemiologic features of Zika cases seen at CanTravNet sites changed. From October 2015 to March 2016, 54\% of the cases were acquired in South America, whereas from April to September 2016, only $4 \%$ of cases were acquired in South America $(p<$ 0.001) (Table 1). Similarly, from October to March, $46 \%$ of the cases were acquired in the Caribbean or Central America. Conversely, from April to September, 93\% were acquired in that region $(p=0.002)$ (Table 1$)$.

Among the travellers with Zika, rash $(n=36 ; 88 \%)$ and fever ( $n=33 ; 80 \%$ ) were the most common presenting symptoms (Table 2). About half reported arthralgia $(n=22 ; 54 \%)$ or myalgia $(n=19 ; 46 \%), 41 \%$ had headache $(n=17)$, and $5(12 \%)$ had conjunctivitis. Two (5\%) travellers with Zika had symptoms 
resembling those of Guillain-Barré syndrome, acutely characterized by peripheral weakness, paresthesia and hyporeflexia; 1 of them also had Zika viral meningitis. One ill traveller with Zika also had related epididymitis. A comparison of presenting symptoms between patients with Zika and those with dengue is provided in Table 2 . In most cases ( $n=28 ; 68 \%$ ), Zika-related symptoms developed during travel; the remainder occurred a median 3 days after travel (range 1-7 d; IQR 2-6 d).

Nineteen $(46 \%)$ of Zika cases were confirmed by serologic testing alone; another 15 (37\%) were confirmed by real-time PCR alone. The remaining 7 (17\%) were found to be positive for Zika virus by both serologic testing and PCR. Most of the travellers with Zika ( $n=32 ; 78 \%$ ) presented for care during the acute phase (within $10 \mathrm{~d}$ after symptom onset) or early convalescent phase (10-30 d after symptom onset); the remaining $9(22 \%)$ presented during late convalescence (> 1 mo after symptom onset). Those who presented during the acute or early convalescent phase were also tested for dengue and chikungunya; $2(5 \%)$ of those with Zika were also positive for chikungunya IgM antibodies, which likely reflects intercurrent or recently acquired chikungunya virus. Among those presenting during the acute or early convalescent phase of Zika virus infection, the median time from symptom onset to assessment at a CanTravNet site was 8 days (range 2-30 d; IQR 5-14 d). Among those in the late convalescent phase of Zika virus infection, the median time from symptom onset to assessment at a CanTravNet clinic was 64 days (range 45-160 d; IQR 50-92 d).
Among travellers with Zika who presented for care during the acute phase $(n=20)$, PCR was positive in $10(50 \%)$ and serologic testing was positive in 15 (75\%); however, only 1 test was positive in 15 (75\%): PCR in 5 (25\%) and serologic testing in 10 (50\%). Among those who presented during the early convalescent phase $(n=11)$, PCR was positive in $7(64 \%)$ and serologic testing was positive in $5(45 \%)$.

Both of the travellers who had symptoms resembling those of Guillain-Barré syndrome presented for care during the acute or early convalescent phase of illness, which yielded an approximate $6 \%$ prevalence of neurologic involvement among the travellers with Zika who presented during the acute or early convalescent phase. In 2 of 3 cases of Zika in pregnant travellers, congenital infection was documented by detection of the virus in fetal tissue. Overall, 4 (10\%) of the 41 travellers with Zika had a severe complication of the infection, as compared with none of the 41 travellers with dengue $(p=0.1)$.

\section{Interpretation}

Our analysis of surveillance data provides demographic and travel-related details for a subset of Canadian travellers who acquired Zika virus in the Americas. We have described our collective 1-year experience with this emerging imported arboviral infection. Our findings show strong potential for secondary transmission in Canada, both sexually and congenitally. Our analysis also establishes a clinical and epidemiologic framework

Table 1: Demographic characteristics of 41 ill travellers presenting to a CanTravNet site for care of Zika virus acquired in the Americas, October 2015 to September 2016*

\begin{tabular}{|c|c|c|c|c|}
\hline \multirow[b]{2}{*}{ Characteristic } & \multicolumn{3}{|c|}{ Acquisition period; no. (\%) of travellers with Zika virus infection $†$} & \multirow[b]{2}{*}{$p$ value $\ddagger$} \\
\hline & $\begin{array}{l}\text { Total } \\
n=41\end{array}$ & $\begin{array}{l}\text { October } 2015 \text { to March } 2016 \\
\qquad n=13\end{array}$ & $\begin{array}{l}\text { April to September } 2016 \\
\qquad n=28\end{array}$ & \\
\hline Sex & & & & 0.7 \\
\hline Male & $17(41)$ & $6(46)$ & $11(39)$ & \\
\hline Female & $24(59)$ & $7(54)$ & $17(61)$ & \\
\hline Age, yr, median (range) & $36(13-70)$ & $36(18-54)$ & $35(13-70)$ & 0.8 \\
\hline \multicolumn{5}{|l|}{ Reason for travel } \\
\hline Tourism & $17(41)$ & $4(31)$ & $13(46)$ & 0.5 \\
\hline Visiting friends and relatives & $15(37)$ & $7(54)$ & $8(29)$ & 0.2 \\
\hline Business & $4(10)$ & $0(0)$ & $4(14)$ & 0.3 \\
\hline Missionary/aid work & $4(10)$ & $2(15)$ & $2(7)$ & 0.6 \\
\hline Education & $1(2)$ & $0(0)$ & $1(4)$ & 1.0 \\
\hline \multicolumn{5}{|l|}{ Region of acquisition } \\
\hline Caribbean & $22(54)$ & $4(31)$ & $18(64)$ & 0.09 \\
\hline Central America & $10(24)$ & $2(15)$ & $8(29)$ & 0.5 \\
\hline South America & $8(20)$ & $7(54)$ & $1(4)$ & $<0.001$ \\
\hline North America & $1(2)$ & $0(0)$ & $1(4)$ & 1.0 \\
\hline
\end{tabular}


for the pre- and post-travel consultation processes: Zika was as common as dengue as a cause of illness upon return from the Americas; neurologic complications of Zika were common; sexual transmission occurred even in this small cohort; and a 2-pronged approach to diagnostic testing is supported by the limited overlap between seropositive and PCR-positive cases.

Even though Zika was diagnosed as often as dengue in this cohort, the rate of complications of acute illness was much higher among those with Zika than among those with dengue. Dengue is one of the most common causes of fever in returned travellers ${ }^{19}$ and a common cause of hospital admission among ill returned travellers in general. Depending on the diagnostic criteria applied, severe dengue is thought to occur in $1 \%$ to $20 \%$ of all imported dengue cases..$^{20,21}$ The common perception that Zika is associated with a more mild or benign clinical course than that of dengue or chikungunya was not borne out in this small cohort. Strong referral bias is unlikely, because the symptoms on presentation were mostly nonspecific, and the practice in the CanTravNet sites is to test most patients for all 3 infections, given common epidemiologic features and vectorial transmission. Accrual of further large-scale data on imported Zika is required to understand the true prevalence of complications of infection among travellers. Because of a lack of vaccine availability or chemoprophylaxis (2 common strategies for prevention of travel-acquired illness), prevention of all 3 arboviral infections relies solely on the use of mosquito-avoidance measures (e.g., screens or netting, insecticide-treated clothing, and insect repellents). ${ }^{22,23}$

Neurologic complications of Zika were observed in $5 \%$ of the travellers in our small cohort. The substantial neurotropism of
Zika virus ${ }^{24,25}$ was supported by our observation of symptoms similar to those of Guillain-Barré syndrome, meningitis and polyneuropathy in 5\% of the travellers with Zika. Populationlevel analysis of neurologic disorders in Colombia has shown that, since the recognition of the Zika virus outbreak, there has been a fourfold increase in the number of reported cases of Guillain-Barré syndrome, but no commensurate increase in reported myelopathies, neuropathies or demyelinating disorders. ${ }^{26}$ Conversely, using hospital admission data available through Brazil's Unified Health System, Barcellos and colleagues ${ }^{27}$ documented a threefold rise in cases of Guillain-Barré syndrome in the northeastern region of Brazil after recognition of the outbreak, and a twofold increase in hospital admissions for encephalitis, myelitis and encephalomyelitis. ${ }^{27}$ Although the proclivity of Zika virus to infect neural tissue is now well described, the full range of clinical manifestations from such neurotropism have yet to be elucidated. This challenges our ability to adequately counsel patients on risk and prognosis. In our small cohort, neurologic complications arose during the acute phrase rather than in convalescence, which is atypical of post-infectious Guillain-Barré syndrome and polyneuropathy. In a patient with neurologic manifestations, particularly meningoencephalitis, and illness clinically compatible with Zika, imaging of the brain and spine, nerve conduction studies and collection of cerebrospinal fluid for cytology, biochemistry and PCR are appropriate investigations beyond what would be routinely done to exclude Zika virus infection.

Congenital and sexual transmission were observed in our cohort. We documented congenital transmission in at least 2 of 3 travellers with Zika who were pregnant. In addition, we

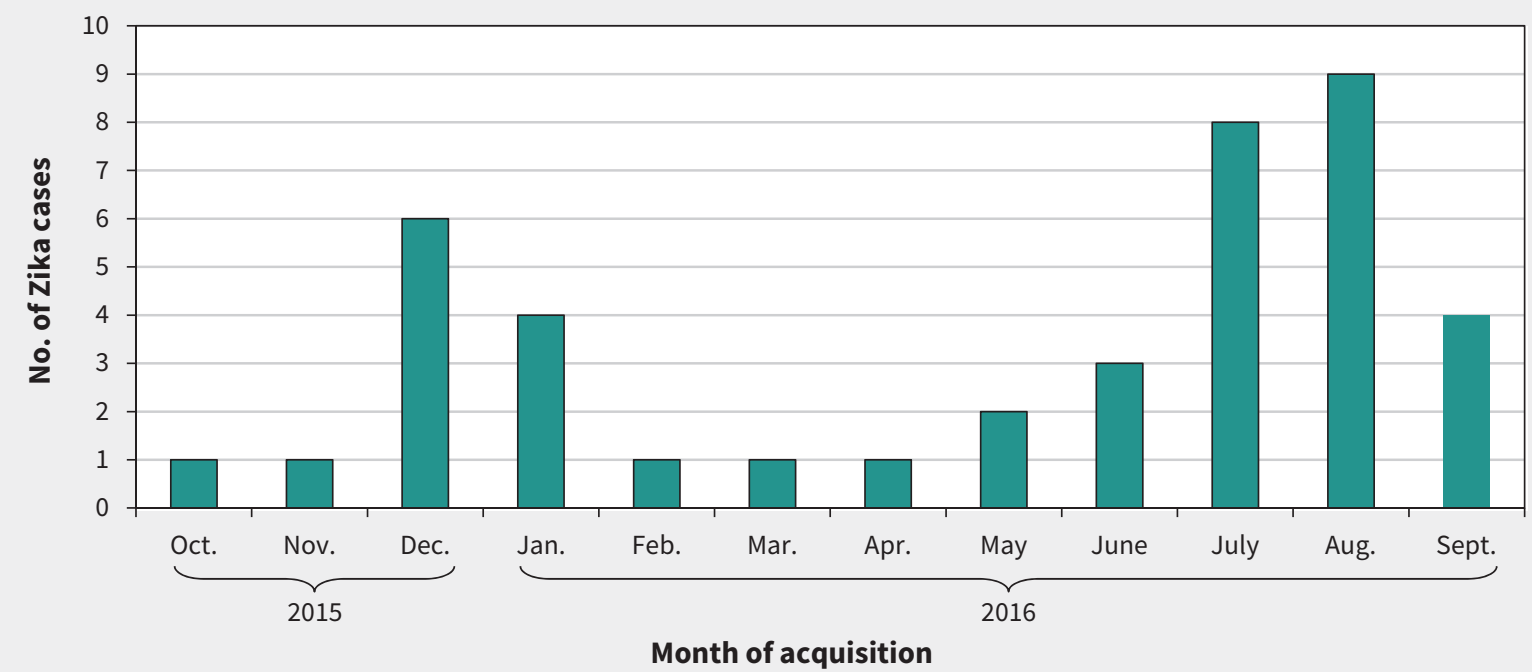

Figure 1: Distribution of 41 cases of Zika virus infection by month of acquisition among ill travellers presenting for care at a CanTravNet site from October 2015 to September 2016. 
documented 1 case of sexual transmission coincident with conception. Furthermore, $80 \%$ of women with Zika were of child-bearing age. The frequency and severity of the newly described congenital Zika syndrome ${ }^{5,6}$ dictates that women who are pregnant avoid travel to areas with ongoing transmission of Zika virus, ${ }^{28}$ and those planning to conceive should consider deferring travel. ${ }^{28}$ The risk of sexual transmission of Zika virus can be reduced through use of condoms and abstinence, ${ }^{28}$ although because of prolonged seminal shedding, practical algorithms for the prevention of sexual transmission remain challenging.

The epidemiologic features of imported Zika virus among Canadians seen at CanTravNet sites may have changed with maturation of the Americas outbreak. Phylogenetic analysis has confirmed the introduction of Zika virus to Brazil in $2013 .{ }^{1} \mathrm{How}$ ever, specific diagnostic testing for Zika virus became available in Canada only in early $2016 .{ }^{28}$ In the first half of the study period in our analysis, the burden of Zika virus was borne by people travelling to the Americas, particularly South America, for the purpose of visiting friends and relatives; in the latter half, coincident with the increased spread of Zika throughout the Caribbean and Central America, the burden was borne more often by tourists travelling to the Caribbean. This finding may reflect travel proclivities among groups of travelling Canadians, seasonality of mosquitoes according to precipitation, or declining transmission rates in regions involved in the early stages of the epidemic. However, it may also reflect more wide-

Table 2: Presenting symptoms of ill travellers with Zika virus infection or dengue who presented to a CanTravNet site, October 2015 to September 2016

\begin{tabular}{|c|c|c|}
\hline \multirow[b]{2}{*}{ Symptom } & \multicolumn{2}{|c|}{ Diagnosis; no. (\%) of travellers } \\
\hline & $\begin{array}{c}\text { Zika virus } \\
\quad n=41\end{array}$ & $\begin{array}{c}\text { Dengue } \\
n=41\end{array}$ \\
\hline Any rash & $36(88)$ & $15(37)$ \\
\hline Fever & $33(80)$ & $36(88)$ \\
\hline Diffuse rash & $29(71)$ & $12(29)$ \\
\hline Arthralgia & $22(54)$ & $12(29)$ \\
\hline Myalgia & $19(46)$ & $20(49)$ \\
\hline Fatigue & $19(46)$ & $9(22)$ \\
\hline Headache & $17(41)$ & $18(44)$ \\
\hline Focal rash & $7(17)$ & $3(7)$ \\
\hline Conjunctivitis & $5(12)$ & $0(0)$ \\
\hline Diarrhea & $5(12)$ & $7(17)$ \\
\hline Cough & $4(10)$ & $4(10)$ \\
\hline Arthritis & $3(7)$ & $2(5)$ \\
\hline Paresthesia & $2(5)$ & $0(0)$ \\
\hline Dyspnea & $1(2)$ & $1(2)$ \\
\hline Epididymitis & $1(2)$ & $0(0)$ \\
\hline Sore throat & $1(2)$ & $0(0)$ \\
\hline Nausea & $1(2)$ & $4(10)$ \\
\hline
\end{tabular}

spread and protective seroconversion among travellers visiting family and friends, who tend to travel repeatedly, stay abroad for longer periods (thereby increasing their chances of infective mosquito bites) and interact more with local residents, who themselves are accumulating immunity but are also a potential source of sexual transmission. At this point, the durability of protection conferred by neutralizing antibody titres in travellers is unknown. However, based on experience with other flaviviruses, it is presumed to be prolonged, if not lifelong. Despite large volumes of Canadians travelling to Florida, no cases were observed from this region.

Fewer than 1 in 5 travellers with Zika virus infection in our analysis had positive results from both serologic and molecular testing. Current Zika testing algorithms in Canada support the use of both serologic and nucleic acid-based tests for confirmation of acute infection, ${ }^{28}$ with molecular testing of serum performing best within the first 5 days of illness, and serologic testing increasing in sensitivity beyond day 7 of illness. Beyond 14 days of illness, testing algorithms support use of isolated serologic testing, ${ }^{28}$ unless the patient is pregnant, which can lead to prolonged viremia and detection of viral RNA in serum. ${ }^{29,30}$ Our data support the 2-pronged testing approach in acute illness, because neither PCR nor serologic testing was sufficiently sensitive for diagnosis in isolation. However, our documentation of viremia in $64 \%$ of travellers with Zika who presented in the early convalescent phase (10$30 \mathrm{~d}$ after symptom onset) counters the general recommendation to avoid PCR beyond 14 days of illness. Our analysis highlights how testing criteria may evolve over time. Newer serologic tests that are designed to minimize cross-reactivity with other flaviviruses and that can be deployed closer to the point of care are currently being evaluated. ${ }^{31,32}$ Implementation of such tests would facilitate access to diagnostic testing and reduce the turnaround time of results.

\section{Limitations}

Analysis of CanTravNet data has several limitations, which have been described previously. ${ }^{14}$ The current analysis pertains only to the sample of ill travellers who presented to a CanTravNet site for care of Zika virus acquired in the Americas. Thus, our conclusions may lack generalizability to other Canadian travellers and to those travelling outside the Americas. Our findings may also lack generalizability to people living in endemic areas.

Our database likely underrepresents the actual burden of Zika among ill travellers returning from the Americas because of the prolonged turnaround time of Zika virus serologic testing. It is highly probable that many more ill travellers who were entered into our database with "suspected" or "probable" Zika virus, or "viral syndrome" will be confirmed to have Zika virus in the future. Moreover, those who acquired mild or asymptomatic Zika virus infection during long-duration travel may not be represented in our database, because they may be less likely to seek care upon return.

Some CanTravNet sites offer rapid assessment of febrile travellers from the affiliated emergency departments, which may bias the data toward those with undifferentiated febrile illness presenting early in the course of their disease. 
We could not estimate incidence rates or destination-specific numerical risks for Zika because of the absence of a total denominator of travellers to the Americas. ${ }^{33}$ The Winnipeg site was new to CanTravNet in 2016, and at the time of writing, it had not contributed cases to the database. Similarly, there are no CanTravNet sites in the Maritime provinces.

Our study was of a 1-year duration. Thus, our conclusions around shifting temporal epidemiologic characteristics of Zika virus infection may be limited and need to be corroborated by analyses of longer duration.

Finally, our clinic sites primarily serve adult returned travellers. As such, pediatric cases are likely underrepresented.

\section{Conclusion}

We have documented the full clinical spectrum of acute Zika virus infection in $12 \%$ of all such cases imported to Canada from the Americas over a 1-year period, including adverse fetal and neurologic outcomes, as well as sexual transmission. Dengue is one of the most common causes of fever in returned travellers, and over our study period, Zika was encountered as frequently as dengue at the CanTravNet sites, which highlights the emergence of this arboviral pathogen in the mobile Canadian population. Prevention of transmission rests on mosquito-avoidance measures, which may include travel deferral, and on barrier protection during sexual activity.

\section{References}

1. Faria NR, Azevedo Rdo S, Kraemer MU, et al. Zika virus in the Americas: early epidemiological and genetic findings. Science 2016;352:345-9.

2. Zika virus infection: global update - Travel health notice [updated 2017 Jan. 5]. Ottawa: Public Health Agency of Canada; 2016. Available: https://travel.gc.ca/ travelling/health-safety/travel-health-notices/152 (accessed 2016 Oct. 11).

3. Rodriguez-Morales AJ, Villamil-Gómez WE, Franco-Paredes C. The arboviral burden of disease caused by co-circulation and co-infection of dengue, chikungunya and Zika in the Americas. Travel Med Infect Dis 2016;14:177-9.

4. Constenla D, de Broucker G, del Campo JM. The potential economic impact of the Zika virus - winter newsletter 2016. Dengue Vaccine Initiative. Available: www. denguevaccines.org/winter-newsletter-2016\#/zika (accessed 2016 June 24).

5. Zika virus fact sheet. Geneva: World Health Organization. Available: www.who. int/mediacentre/factsheets/zika/en/ (accessed 2016 Sept. 10).

6. Panchaud A, Stojanov M, Ammerdorffer A, et al. Emerging role of Zika virus in adverse fetal and neonatal outcomes. Clin Microbiol Rev 2016;29:659-94.

7. All countries and territories with active Zika virus transmission [updated 2016 Dec. 16]. Atlanta: Centers for Disease Control and Prevention. Available: www. cdc.gov/zika/geo/active-countries.html (accessed 2016 Dec. 9).

8. Alejo-Cancho I, Torner N, Oliveira I, et al. Twenty-four cases of imported zika virus infections diagnosed by molecular methods. Diagn Microbiol Infect Dis 2016;86:160-2.

9. Lustig Y, Mendelson E, Paran N, et al. Detection of Zika virus RNA in whole blood of imported Zika virus disease cases up to 2 months after symptom onset, Israel, December 2015 to April 2016. Euro Surveill 2016;21:30269.

10. D'Ortenzio E, Matheron S, Yazdanpanah Y, et al. Evidence of sexual transmission of Zika virus. N Engl J Med 2016;374:2195-8.
11. Deckard DT, Chung WM, Brooks JT, et al. Male-to-male sexual transmission of Zika virus - Texas, January 2016. MMWR Morb Mortal Wkly Rep 2016; 65:372-4.

12. Muñoz LS, Barreras P, Pardo CA. Zika virus-associated neurological disease in the adult: Guillain-Barré syndrome, encephalitis, and myelitis. Semin Reprod Med 2016;34:273-9.

13. Meltzer E, Leshem E, Lustig $\mathrm{Y}$, et al. The clinical spectrum of Zika virus in returning travelers. Am J Med 2016;129:1126-30.

14. Boggild AK, Geduld J, Libman M, et al. Travel acquired infections in Canada: CanTravNet 2011-2012. Can Commun Dis Rep 2014;40:313-25.

15. Leder K, Torresi J, Libman M, et al. GeoSentinel Surveillance Network. GeoSentinel surveillance of illness in returned travelers, 2007-2011. Ann Intern Med 2013;158: 456-68.

16. Leder K, Tong S, Weld L, et al. GeoSentinel Surveillance Network. Illness in travelers visiting friends and relatives: a review of the GeoSentinel Surveillance Network. Clin Infect Dis 2006;43:1185-93.

17. Dengue: guidelines for diagnosis, treatment, prevention and control. Geneva: World Health Organization; 2009. Available: www.who.int/tdr/publications/ documents/dengue-diagnosis.pdf?ua=1 (accessed 2016 Oct. 19).

18. Surveillance of Zika virus. Ottawa: Public Health Agency of Canada; 2017. Available: http://healthycanadians.gc.ca/diseases-conditions-maladies-affections/ disease-maladie/zika-virus/surveillance-eng.php?id=zikacases\#s1 (accessed 2016 Oct. 11).

19. Boggild AK, Ghesquiere W, McCarthy A; Committee to Advise on Tropical Medicine and Travel (CATMAT). Fever in the returning international traveller: initial assessment guidelines. Can Commun Dis Rep 2011;37:1-15.

20. Wichmann O, Gascon J, Schunk M, et al.; European Network on Surveillance of Imported Infectious Diseases. Severe dengue virus infection in travelers: risk factors and laboratory indicators. J Infect Dis 2007;195:1089-96.

21. Meltzer E, Schwartz E. A travel medicine view of dengue and dengue hemorrhagic fever. Travel Med Infect Dis 2009;7:278-83.

22. Schofield S, Plourde P; Committee to Advise on Tropical Medicine and Travel (CATMAT). Statement on personal protective measures to prevent arthropod bites. Can Commun Dis Rep 2012;38:1-18. Available: www.phac -aspc.gc.ca/publicat/ccdr-rmtc/12vol38/acs-dcc-3/index-eng.php (accessed 2016 June 24).

23. Rodriguez SD, Drake LL, Price DP, et al. The efficacy of some commercially available insect repellents for Aedes aegypti (Diptera: Culicidae) and Aedes albopictus (Diptera: Culicidae). J Insect Sci 2015;15:140.

24. Broutet N, Krauer F, Riesen M, et al. Zika virus as a cause of neurologic disorders. N Engl J Med 2016;374:1506-9.

25. Muñoz LS, Barreras P, Pardo CA. Zika virus-associated neurological disease in the adult: Guillain-Barré syndrome, encephalitis, and myelitis. Semin Reprod Med 2016;34:273-9.

26. Machado-Alba JE, Machado-Duque ME, Gaviria-Mendoza A, et al. Diagnosis of neurological disorders and Zika virus epidemic in Colombia 2014-2016. Int J Infect Dis 2016;51:133-4.

27. Barcellos C, Xavier DR, Pavão A, et al. Increased hospitalizations for neuropathies as indicators of Zika virus infection, according to Health Information System Data, Brazil. Emerg Infect Dis 2016;22:1894-9.

28. Canadian recommendations on the prevention and treatment of Zika virus: update. Can Commun Dis Rep 2016;42:101-11. Available: www.phac-aspc.gc. ca/publicat/ccdr-rmtc/16vol42/dr-rm42-5/assets/pdf/16vol42_5-ar-01-eng.pdf (accessed 2016 June 24). 
29. Meaney-Delman D, Oduyebo T, Polen KN, et al.; U.S. Zika Pregnancy Registry Prolonged Viremia Working Group. Prolonged detection of Zika virus RNA in pregnant women. Obstet Gynecol 2016;128:724-30.

30. Driggers RW, Ho CY, Korhonen EM, et al. Zika virus infection with prolonged maternal viremia and fetal brain abnormalities. N Engl J Med 2016;374:2142-51.

31. Huzly D, Hanselmann I, Schmidt-Chanasit J, et al. High specificity of a novel Zika virus ELISA in European patients after exposure to different flaviviruses. Euro Surveill 2016;21:30203.
32. Anti-Zika virus ELISA (IgM): test instruction. Lübeck (Germany): EUROIMMUN AG Available: www.fishersci.com/content/dam/fishersci/en_US/documents/ programs/healthcare/technical-documents/package-inserts/zika-test-package -insert.pdf (accessed 2016 Sept. 12).

33. Leder K, Steffen R, Cramer JP, et al. Risk assessment in travel medicine: how to obtain, use, and interpret risk data for informing pre-travel advice. J Travel Med 2015;22:13-20.
Competing interests: Andrea Boggild, Michael Libman and Anne McCarthy serve on the Committee to Advise on Tropical Medicine and Travel, an external advisory body to the Public Health Agency of Canada. Cedric Yansouni has received research grants from BD Molecular Diagnostics and bioMérieux for projects unrelated to the current study. David Freedman serves on the World Health Organization Zika Emergency Committee and receives salary support from Shoreland Travax, an online medical publisher; he also has received consultant fees from UpToDate Inc. and Antimicrobial Inc. Kevin Kain has received operating grants from the Canadian Institutes of Health Research and from Global Alliance to Prevent Prematurity and Stillbirth, and Grand Challenges in Global Health; he receives salary support as a Canada Research Chair in Molecular Parasitology. No other competing interests were declared.

This article has been peer reviewed.

Affiliations: Department of Medicine (Boggild, Chakrabarti, Kain), Tropical Disease Unit, Division of Infectious Diseases, University Health Network and University of Toronto; Public Health Ontario Laboratories (Boggild), Public Health Ontario, Toronto, Ont.; Office of Border and Travel Health (Geduld), Public Health Agency of Canada, Ottawa, Ont.; The J.D. MacLean Centre for Tropical Diseases (Libman, Yansouni), McGill University, Montréal, Que.; Tropical Medicine and International Health
Clinic (McCarthy), Division of Infectious Diseases, Ottawa Hospital and University of Ottawa, Ottawa, Ont.; Division of Infectious Diseases (Hajek, Mirzanejad), University of British Columbia, Vancouver, BC; Infectious Diseases (Ghesquiere), Vancouver Island Health Authority, Victoria, BC; Department of Medicine (Ghesquiere), University of British Columbia, Vancouver, BC; Fraser Health (Mirzanejad), Surrey, BC; Hôpital Saint-Luc du CHUM (Vincelette), Université de Montréal, Montréal, Que.; Departments of Pediatrics and Medicine (Kuhn), Section of Pediatric Infectious Diseases, Alberta Children's Hospital and University of Calgary, Calgary, Alta.; Travel Health and Tropical Medicine Services (Plourde), Population and Public Health Program, Winnipeg Regional Health Authority, Winnipeg, Man.; Trillium Health Partners (Chakrabarti), Mississauga, Ont.; Department of Medicine (Freedman), Center for Geographic Medicine, University of Alabama Birmingham, Birmingham, Ala.; SAR Laboratories (Kain), Sandra Rotman Centre, Toronto, Ont.

Contributors: Andrea Boggild conceived the study, contributed to the study design, and the data collection, analysis and interpretation, and was primarily responsible for writing the manuscript. Jennifer Geduld contributed to the study conception and data interpretation. Jean Vincelette contributed to the data collection, analysis and interpretation. Michael Libman,
Cedric Yansouni, Anne McCarthy, Jan Hajek, Wayne Ghesquiere, Yazdan Mirzanejad, Susan Kuhn, Sumontra Chakrabarti and Kevin Kain contributed to the data collection and interpretation. Pierre Plourde and David Freedman contributed to the data interpretation. All of the authors critically revised the manuscript for important intellectual content, approved the final version to be published and agreed to act as guarantors of the work.

Funding: CanTravNet is funded through the Public Health Agency of Canada's Office of Border and Travel Health. It was created by grouping the Canadian sites of GeoSentinel, a global surveillance network of the International Society of Travel Medicine (ISTM), which is supported by Cooperative Agreement U50/ CCU412347 from the US Centers for Disease Control and Prevention and the ISTM. The funding sources of GeoSentinel had no role in the study design, data analysis, data interpretation or drafting of the manuscript. The funding source of CanTravNet contributed to the study design and critical appraisal of the manuscript, but it did not have access to raw data.

Accepted: Jan. 12, 2017

Correspondence to: Andrea Boggild, andrea.boggild@utoronto.ca 